\title{
Effect of Bleaching Protocols with $38 \%$ Hydrogen Peroxide and Post-Bleaching Times on Dentin Bond Strength
}

\author{
Aline Evangelista SOUZA-GABRIEL \\ Lilian Oliveira Cambaúva VITUSSI \\ Camila MILANI \\ Edson ALFREDO \\ Danielle Cristine Furtado MESSIAS \\ Yara Teresinha Correa SILVA-SOUSA
}

Dental School, UNAERP - University of Ribeirão Preto, Ribeirão Preto, SP, Brazil

\begin{abstract}
This study assessed the effect of bleaching protocols with $38 \%$ hydrogen peroxide (HP) and post-bleaching times on shear bond strength of a composite resin to dentin. One-hundred slabs of intracoronary dentin were included and randomly assigned into 2 groups according to the bleaching protocol: HP (2 applications of $10 \mathrm{~min}$ each) and HP activated by LED laser ( 2 applications of $10 \mathrm{~min}$ each/45 $\mathrm{s}$ of light activation). Groups were subdivided according to the post-bleaching time $(n=10)$ : 1 day, 3 days, 7 days, 10 days and 14 days. The control group was unbleached and restored $(\mathrm{n}=10)$. The specimens were restored with Single Bond adhesive system/Filtek Z250 resin using a polytetrafluorethylene matrix and were submitted to the shear bond strength testa after $24 \mathrm{~h}$,. Data were analyzed by ANOVA and Tukey's test $(\alpha=0.05)$. Unbleached group $(0.283 \pm 0.134)$ had the highest bond strength and was statistically similar ( $\mathrm{p}>0.05)$ to $\mathrm{HP} / 10$ days $(0.278 \pm 0.064), \mathrm{HP}+\mathrm{LED}$ laser/10 days $(0.280 \pm 0.078), \mathrm{HP} / 14$ days $(0.281 \pm 0.104), \mathrm{HP}+\mathrm{LED}$ laser/14 days $(0.277$ $\pm 0.093)$. Lower bond strength were verified in HP/1 day $(0.082 \pm 0.012), \mathrm{HP} / 3$ days $(0.079 \pm 0.013), \mathrm{HP}+\mathrm{LED}$ laser/1 day $(0.073$ $\pm 0.018)$ and HP + LED laser/3 days $(0.080 \pm 0.015)$, which were statistically similar $(\mathrm{p}>0.05)$. HP/7 days $(0.184 \pm 0.154)$ and $\mathrm{HP}+$ LED laser/7 days $(0.169 \pm 0.102)$ had intermediate values $(\mathrm{p}<0.05)$. The restorative procedure of intracoronary dentin bleached with $38 \%$ HP with or without the use of light source should be performed after at least 10 days after the bleaching treatment.
\end{abstract}

Key Words: shear bond strength, hydrogen peroxide, bleaching, post-time bleaching.

\section{INTRODUCTION}

Tooth bleaching is a procedure in which chemical products catalyzed or not by heat or light sources promote chromatic alterations in the dental tissues. Bleaching agents act by an oxidation-reduction reaction with the darkened substrate (1-3). When the whitening agent is placed into the pulp chamber, reactive oxygen is released from the degradation of the bleaching agent, the colored substance is chemically reduced and transformed into a colorless material, producing the whitening effect (3).

Due to its reactive properties, hydrogen peroxide (HP) is the main active chemical component of most agents used in tooth bleaching therapies. HP can be used in its pure form or as the final product of the degradation of other bleaching substances, such as sodium perborate and carbamide peroxide (2).

Light sources are used to catalyze the bleaching process by intensifying the oxi-reduction reaction and accelerating the release of hydroxyl $(\mathrm{OH}-)$ radicals $(4,5)$. Light-emitting diode (LED)-laser system is a cost-effective alternative to other light sources, with less energy needed to generate light (6). The LED-laser is a cold light originated from semiconductors and provides less heat generation (4,6). Additionally, it has been shown to be more efficient compared to halogen lamps (5).

The clinical performance of resin-based composite restorations after the bleaching procedure can be influenced by possible alterations from presence of bleaching agents in the dental structure (7-11). Free

Correspondence: Profa. Dra. Aline Evangelista Souza-Gabriel, Avenida Portugal, 1690, apto. 84, Jardim São Luis, 14020-380 Ribeirão Preto, SP, Brasil. Tel: +55-16-3877-8303. Fax:+55-16-. e-mail: aline.gabriel@gmail.com 
radicals from oxygen that remain in the dental tissues can inhibit the light activation of resin materials with subsequent reduction in bond strength of resin-based composite restorations $(8,11)$.

A waiting time between the bleaching procedure and restorative treatment should be allowed to eliminate the residual oxygen from the dental substrate to return to condition that leads to normal bond strengths $(7,9,10,12)$. Nevertheless, the appropriate post-bleaching time interval following the bleaching treatment is not well established. Therefore, this in vitro study evaluated the influence of delaying the restorative procedure for different time intervals following bleaching with 38\% $\mathrm{HP}$ at different protocols on shear bond strength of a resin composite restoration to intracoronary dentin.

\section{MATERIAL AND METHODS}

The study protocol was reviewed and approved by the University Ethics' Committee (Protocol number 084/2010).

\section{Experimental Design}

The factors under study were dental bleaching at 2 levels: 38\% hydrogen peroxide (Opalescence Xtra Boost; Ultradent Products Inc., UT, USA) and 38\% hydrogen peroxide + activation with LED-laser (Brightness; Kondortech, São Carlos, SP, Brazil), and post-bleaching time intervals to restoration at 5 levels: immediate, 3, 7, 10 and 14 days. One-hundred intracoronary specimens were randomly assigned into these 10 experimental groups $(\mathrm{n}=10)$. Ten additional slabs were part of a control group that was not subjected to bleaching and was restored. The response variable was shear bond strength to the intracoronary dentin.

\section{Dentin Sample Preparation}

Fifty-five human superior canines stored in $0.1 \%$ thymol solution at $4^{\circ} \mathrm{C}$ were washed in running water for $24 \mathrm{~h}$ to eliminate thymol residues. Teeth were examined under a $\times 20$ magnifier (Leica Microsystems, Wetzlar, Germany) to discard those with structural defects as fissures and defective grooves. Roots were sectioned $2 \mathrm{~mm}$ below the cementoenamel junction. Crowns were fixed in wax, bisected longitudinally in a mesiodistal direction using a double-faced diamond disk (KG Sorensen, Barueri, SP, Brazil) and mounted in a low-speed handpiece (Dabi Atlante, Ribeirão Preto, SP, Brazil). Each crown half was sectioned in the incisal, mesial, distal and cervical faces to obtain 5-mm wide $\mathrm{x}$ 5-mm high $\left(25 \mathrm{~mm}^{2}\right)$ slabs, totalizing 110 slabs.

The fragments were embedded in self-polymerized acrylic resin (Jet; Clássico Produtos Odontológicos Ltda., São Paulo, SP, Brazil) surrounded by a polyvinyl chloride (PVC) cylinder $(1.5-\mathrm{cm}$ diameter and $1.5-\mathrm{cm}$ high) with the intracoronary dentin faced up. After resin polymerization, the PVC cylinder was removed and the dentin surface was ground with 280- and 400grit silicon carbide (SiC) paper (Norton, Lorena, SP, Brazil) under water cooling to obtain flat dentin surface. Complementary grinding was accomplished with 1200grit $\mathrm{SiC}$ paper for $1 \mathrm{~min}$ to produce a standardized smear layer. The specimens were irrigated with $10 \mathrm{~mL}$ of $1 \%$ sodium hypochlorite to simulate the irrigation protocol performed during biomechanical preparation of the root canals.

\section{Bleaching Treatment}

The specimens were randomly assigned to 2 groups, according to the surface treatment: bleached with 38\% HP (Opalescence Xtra Boost) and bleached with 38\% hydrogen peroxide activated by the LED-laser system (Brightness; Kondortech).

The red activator was mixed with the colorless bleaching gel at the moment of use, according to the manufacturer's instructions. The bleaching gel was applied to the dentin surface for $10 \mathrm{~min}$. In the group activated by LED-laser, the light was applied for $45 \mathrm{~s}$. The bleaching protocol was repeated 3 times, with a 5-min interval between them. The gel was aspirated, and the surfaces were washed with distilled water and dried with oil-free compressed air.

\section{Shear Bond Strength Test}

The specimens were subdivided according to the post-bleaching time intervals previously the restoration $(\mathrm{n}=10)$ : immediately, 3 days, 7 days, 10 days and 14 days after the bleaching procedure. The bleached specimens were kept in artificial saliva at $37^{\circ} \mathrm{C}$ until restoration.

The dentin surfaces were etched with $37 \%$ phosphoric acid (3M ESPE, St. Paul, MN, USA) for 15 $\mathrm{s}$, washed with a water spray and dried with absorbent points. Single Bond adhesive system (3M ESPE) was applied according to the manufacturer's instructions 
and light activated for $10 \mathrm{~s}$ using a halogen light-curing unit (Dabi Atlante).

Dentin surface were restored using a split Teflon matrix $(3 \times 3 \times 4 \mathrm{~mm})$ stabilized with addition silicone impression material. The specimens received the application of the Filtek Z250 resin (3M ESPE), and the material was polymerized for $20 \mathrm{~s}$ (Dabi Atlante). Sequentially, the silicone contention was removed and the matrix was carefully opened, leaving a resin rectangle adhered to the dentin surface. A complementary polymerization for $20 \mathrm{~s}$ was accomplished to ensure that specimen was adequately polymerized. The specimens were kept in artificial saliva at $37^{\circ} \mathrm{C}$ for $24 \mathrm{~h}$.

Specimens were subjected to shear bond strength test in an universal testing machine (Instron 4444; Instron Corporation, Canton, MA, USA) at a $0.5 \mathrm{~mm} / \mathrm{min}$ crosshead speed and a $2 \mathrm{kN}$ load cell until displacement of the restoration. Shear bond strength values were registered in $\mathrm{kN}$.

The resin/dentin interface of the fractured specimens was analyzed under a stereoscopic microscope at $\times 40$ magnification (Leica Microsystems), and displayed as percent values. Failure was considered adhesive if it occurred at the dentin/adhesive interface, cohesive if it occurred within the material or the substrate, and mixed if it involved both the interface and the material.

Table 1. Shear bond strength means (in $\mathrm{kN}$ ) and standard deviations of the of restorative material to dentin and failure types after test in the different experimental groups.

\begin{tabular}{|c|c|c|c|c|}
\hline \multirow{2}{*}{$\begin{array}{l}\text { Experimental } \\
\text { groups }\end{array}$} & \multirow{2}{*}{$\begin{array}{c}\text { Bond strength }(\mathrm{kN}) \\
\text { Means } \pm \mathrm{SD}\end{array}$} & \multicolumn{3}{|c|}{ Failure mode $(\%)$} \\
\hline & & Adhesive & Cohesive & Mixed \\
\hline Non-bleached teeth (control) & $0.283 \pm 0.134 \mathrm{a}$ & 40 & 10 & 50 \\
\hline HP/1 day & $0.082 \pm 0.012 \mathrm{~b}$ & 70 & 0 & 30 \\
\hline $\mathrm{HP} / 3$ days & $0.079 \pm 0.013 \mathrm{~b}$ & 80 & 0 & 20 \\
\hline $\mathrm{HP} / 7$ days & $0.184 \pm 0.154 \mathrm{ab}$ & 60 & 0 & 40 \\
\hline $\mathrm{HP} / 10$ days & $0.278 \pm 0.064 \mathrm{a}$ & 60 & 0 & 40 \\
\hline HP/14 days & $0.281 \pm 0.104 \mathrm{a}$ & 50 & 10 & 40 \\
\hline HP + LED-laser/1 days & $0.073 \pm 0.018 \mathrm{~b}$ & 80 & 0 & 20 \\
\hline HP + LED-laser $/ 3$ days & $0.080 \pm 0.015 \mathrm{~b}$ & 90 & 0 & 10 \\
\hline HP + LED-laser/7 days & $0.169 \pm 0.102 \mathrm{ab}$ & 40 & 0 & 60 \\
\hline HP + LED-laser/10 days & $0.280 \pm 0.078 \mathrm{a}$ & 40 & 10 & 50 \\
\hline HP + LED-laser/14 days & $0.277 \pm 0.093 \mathrm{a}$ & 60 & 0 & 40 \\
\hline
\end{tabular}

Different letters indicate statistically significant difference (Tukey-Krammer test, $\mathrm{p}<0.05$ )..

\section{Statistical Analysis}

Shear bond strength data expressed as means and standard deviations were analyzed by ANOVA and Tukey-Kramer test for multiple comparisons at a 0.05 significance level (Instat Program; GraphPad Software, San Diego, CA, USA).

\section{RESULTS}

Shear bond strength means (in $\mathrm{kN}$ ) and standard deviations of the of restorative material to dentin and failure types after test in the different experimental groups are presented in Table 1 .

There was statistically significant differences ( $p=0.0065$ ) among the bleaching protocols and among the post-bleaching times. The unbleached group (control) $(0.283 \pm 0.134)$ had the highest bond strength mean and was statistically similar ( $\mathrm{p}>0.05$ ) to groups: HP/10 days $(0.278 \pm 0.064), \mathrm{HP}+\mathrm{LED}$ laser/10 days $(0.280 \pm$ 0.078), HP/14 days (0.281 \pm 0.104$), \mathrm{HP}+\mathrm{LED}$ laser/14 days $(0.277 \pm 0.093)$ and statistically different $(p<0.05)$ from the others.

Significantly lower bond strength values were verified in groups: HP/1 day $(0.082 \pm 0.012), \mathrm{HP} / 3$ days $(0.079 \pm 0.013), \mathrm{HP}+\mathrm{LED}$ laser/ 1 day $(0.073$ $\pm 0.018)$ and HP + LED laser/3 days $(0.080 \pm 0.015)$, which were statistically similar ( $>0.05) . \mathrm{HP} / 7$ days $(0.184 \pm$ $0.154)$ and HP + LED laser/7 days $(0.169 \pm 0.102)$ had intermediated values $(\mathrm{p}<0.05)$.

The analysis of failure type after the shear bond strength test demonstrated the predominance of mixed failure in the control group (unbleached). The specimens that received the bleaching treatment, regardless of the postbleaching time interval, exhibited a predominance of adhesive failures. Cohesive failures were verified only unbleached specimens and those with post-bleaching time of 10 and 14 days (Table 1).

\section{DISCUSSION}

High-concentrated HP is 
one of the most used bleaching agents in non-vital teeth. Due to its low molecular weight, its degradation products (oxygen and perhydroxyl) are able to penetrate into tooth structure (10). However, temporary filling materials need to be replaced by composite resin restorations (13) and, thus, the post-bleaching time that needs to elapse before the restoration is important to be evaluated (12).

The bleaching agent used in this study (Opalescence Xtra Boost) contains carotene as lightabsorbing agent and, although this is a chemically activated product, the manufacturer reports that some professionals prefer to activate the bleaching gel using a light source (11). The results of the present study, revealed that bleaching intracoronary dentin with $38 \%$ HP was similar to $38 \%$ HP activated by LED-laser system. This is probably due to the fact that LED light did not produce significant temperature rise on dentin $(4,6)$ and, consequently, did not generate thermal adverse effects that could affect the bond strength of restorative material (5). Although LED-laser is a viable light system that does not heat tooth structure, it has been shown that its use does not increase the bleaching efficacy (14). Therefore, the outcomes of this study rejects the hypothesis of a correlation between LED-laser light activation and bond strength decrease in teeth undergoing internal bleaching.

Regarding post-bleaching time intervals, it was observed a decrease of shear bond strength of resin to dentin when the restoration was performed immediately, 3 days and 7 days after bleaching, regardless of the light activation. The decrease in bond strength is due to the properties of peroxide and their action on dental tissues. Because of its high oxidation potential, $\mathrm{OH}^{-}$radicals act in intertubular and peritubular dentin breaking the polypeptide chains and collagen and hyaluronic acid, thereby, attacking the organic component of dentin (15). These morphological alterations increase dentin permeability $(16,17)$ and reduce hardness $(18)$, which may be intensified by a higher exposure of dentin to the bleaching agent. Additionally, HP degradation causes the release of water and free radicals from oxygen (9). The oxygen liberation can interfere in the penetration of resin into dentinal tubules, as well as to inhibit their polymerization $(7,10)$.

The delay in performing the resin restoration (10 and 14 days), also regardless of light use, produced bond strength values similar of those achieved with the unbleached specimens (control). The interval of 10 and 14 days before the resin restoration nullifies the effect of residual oxygen in dentin tubules. A recent in situ (10) study demonstrated that 7 days after completion of the bleaching with $35 \% \mathrm{HP}$, the bond strength to dentin increased to values similar to those found in the unbleached group. According to Shinohara et al. (7) and Barbosa et al. (9), a 14-day interval is sufficient to place composite resin restorations in dentin after bleaching. However, no previous study evaluated the elapsed time following the bleaching treatment of 10 day.

In this study, it was verified the prevalence of the adhesive failure mode in all the bleached specimens, regardless of the protocol or post-bleaching times. This fact can be explained by the methodology used since the shear bond strength acts directly at the adhesive interface causing the separation of the restoration from dentin. Some cohesive failures were observed only in groups with higher bond strength (unbleached, and bleached and restored after 10 and 14 days).

Overall, this study leads to conclusion that the restorative procedure of intracoronary dentin bleached with $38 \%$ HP, with or without the use of light source, should be performed after at least 10 days of the bleaching treatment. The precise mechanism by which the bleaching agents act on dentin is not yet clearly established. Other bleaching agents and analytical methods should be tested in future studies to obtain more information about the impact of bleaching on dental tissues.

\section{RESUMO}

Este estudo avaliou o efeito de protocolos de clareamento com peróxido de hidrogênio $38 \%(\mathrm{PH})$ e tempos pós-clareamento na resistência ao cisalhamento de uma resina composta à dentina. Cem fragmentos de dentina intracoronária foram incluídos e distribuídos aleatoriamente em 2 grupos experimentais de acordo com o protocolo de clareamento: PH (2 aplicações de 10 min cada) e HP ativado por LED laser (2 aplicações de $10 \mathrm{~min}$ cada/45 s de ativação pela luz). Os grupos foram subdivididos de acordo com o tempo pós-clareamento $(n=10)$ : 1 dia, 3 dias, 7 dias, 10 dias e 14 dias. O grupo controle não foi clareado e apenas restaurado $(\mathrm{n}=10)$. Os espécimes foram restaurados com sistema adesivo Single Bond/resina Filtek Z250 usando matriz de teflon. Após $24 \mathrm{~h}$, foram submetidos ao teste de cisalhamento. Os dados foram analisados por ANOVA e teste de Tukey $(\alpha=0,05)$. O grupo não clareado $(0,283 \pm 0,134)$ apresentou a maior resistência de união e foi estatisticamente semelhante $(\mathrm{p}>0,05)$ ao $\mathrm{PH}-10$ dias $(0,278 \pm 0,064), \mathrm{PH}+\mathrm{LED}$ laser/10 dias $(0,280 \pm 0,078), \mathrm{PH} / 14$ dias $(0,281 \pm 0,104), \mathrm{PH}+$ LED laser/14 dias $(0,277 \pm 0,093)$. Resistência de união inferior foram verificadas para $\mathrm{PH} / 1$ dia $(0,082 \pm 0,012), \mathrm{PH} / 3$ dias $(0,079 \pm 0,013), \mathrm{PH}+$ LED laser $/ 1$ dia $(0,073 \pm 0,018)$ e PH + LED laser/3 dias $(0,080 \pm 0,015)$, que foram estatisticamente semelhantes entre si $(p>0,05)$. HP/7 
dias $(0,184 \pm 0,154)$ e PH + LED laser/7 dias $(0,169 \pm 0,102)$ apresentaram valores intermediários $(\mathrm{p}<0,05)$. O procedimento restaurador da dentina intracoronária clareada com peróxido de hidrogênio $38 \%$, com ou sem o uso de fonte de luz, deve ser realizado pelo menos após 10 dias do tratamento clareador.

\section{REFERENCES}

1. Joiner A. The teeth bleaching: a review of the literature. J Dent 2006;34:412-419.

2. Plotino G, Buono L, Grande NM, Pameijer CH, Somma F. Nonvital tooth bleaching: a review of the literature and clinical procedures. J Endod 2008;34:394-407.

3. Dahl JE, Pallesen U. Tooth bleaching: a critical review of the biological aspects. Crit Rev Oral Biol Med 2003;14:292-304.

4. Zhang C, Wang X, Kinoshita JI, Zhao B, Toko T, Kimura Y, et al.. Effect of KTP laser irradiation, diode laser, and LED on tooth bleaching: a comparative study. Photomed Laser Surg 2007;25:9195.

5. Coelho RA, Oliveira AG, Souza-Gabriel AE, Silva SR, SilvaSousa YT, Silva RG. Ex-vivo evaluation of the intrapulpal temperature variation and fracture strength in teeth subjected to different external bleaching protocols. Braz Dent J 2011;22:32-36.

6. Wetter NU, Barroso MCS, Pelino JEP. Dental bleaching efficacy with diode laser and LED irradiation: an in vitro study. J Clin Laser Med Surg 2004;35:254-258

7. Shinohara MS, Peris AR, Pimenta LA, Ambrosano GM. Shear bond strength evaluation of composite resin on enamel and dentin after nonvital bleaching. J Esthet Restor Dent 2005;17:22-29.

8. Timpawat S, Nipattamanon C, Kysamnmith K, Messer HH. Effect of bleaching agents on bonding to pulp chamber dentine. Int Endod J 2005;38:211-217.

9. Barbosa CM, Sasaki RT, Florio FM, Basting RT. Influence of time on bond strength after bleaching with $35 \%$ hydrogen peroxide. J
Contemp Dent Pract 2008;9:81-88.

10. Bittencourt ME, Trentin MS, Linden MS, de Oliveira Lima Arsati YB, França FM, Flório FM, et al.. Influence of in situ postbleaching times on shear bond strength of resin-based composite restorations. J Am Dent Assoc 2010;141:300-306.

11. Ferreira EA, Souza-Gabriel AE, Silva-Sousa YT, Sousa-Neto MD, Silva RG. Shear bond strength and ultrastructural interface analysis of different adhesive systems to bleached dentin. Microsc Res Tech 2010 [Epub ahead of print. DOI: 10.1002/jemt.20895].

12. Teixeira EC, Turssi CP, Hara AT, Serra MC. Influence of postbleaching time intervals on dentin bond strength. Braz Oral Res 2004; 18:75-89.

13. Azevedo RA, Silva-Sousa YT, Souza-Gabriel AE, Messias DC, Alfredo E, Silva RG. Fracture resistance of teeth subjected to internal bleaching and restored with different procedures. Braz Dent J 2011;22:117-121

14. Gurgan S, Cakir FY, Yazici E. Different light-activated inoffice bleaching systems: a clinical evaluation. Lasers Med Sci 2010;25:817-822.

15. Kawamoto K, Tsujimoto Y. Effects of the hydroxyl radical and hydrogen peroxide on tooth bleaching. J Endod 2004;30:45-50.

16. Carrasco LD, Fröner IC, Corona SAM, Pécora JD. Effect of internal bleaching agents on dentinal permeability of non-vital teeth: quantitative assessment. Dent Traumatol 2003;19:85-89.

17. Rodrigues LM, Vansan LP, Pécora JD, Marchesan MA Permeability of different groups of maxillary teeth after $38 \%$ hydrogen peroxide internal bleaching. Braz Dent J 2009;20:303306.

18. Oliveira DP, Teixeira ECN, Ferraz CCR, Teixeira FB. Effect of intracoronal bleaching agents on dentin microhardness. J Endod $2007 ; 33: 460-462$.

Received November 25, 2010

Accepted May 10, 2011 